\title{
Sugar-modulated gene expression of sucrose synthase in suspension-cultured cells of rice
}

\author{
Yi-Chun Liao and Ai-Yu Wang* \\ Department of Agricultural Chemistry, National Taiwan University, 1 Roosevelt Road Section 4, Taipei 106, Taiwan \\ *Corresponding author, e-mail: aywang@ccms.ntu.edu.tw
}

Received 3 September 2002; revised 19 December 2002

In suspension-cultured cells of rice (Oryza sativa L.cv. Tainung 67), two sucrose synthase genes, RSus1 and RSus2, were found to be differentially regulated by sugars. Exogenously provided sugars triggered marked accumulation of the RSus1 transcripts and this required de novo synthesized proteins. In addition to being regulated at the transcriptional level, other regulatory mechanisms might be involved in the sugar-modulated expression of RSus1 since the RSuS1 proteins were extremely stable in sucrose-depleted cells. Glucose analogues, 3- $O$-methyl glucose, 6-deoxyglucose and mannose, did not trigger the induction of RSus 1 expression, suggesting that hexose uptake per se and hexokinase are not involved in the sugar-sensing pathway controlling $R$ Sus 1 expression. The accumulation of $R S u s 2$ mRNA was observed regardless of the presence or absence of sugars. However, newly synthesized proteins induced by sucrose and/or starvation were involved in the regulation of $R S u s 2$ expression at transcriptional and/or post-transcriptional levels. The protein level of RSuS2 was elevated under prolonged starvation condition but a reciprocal change was observed in the sucrose-fed cell. The constant presence of RSuS1 and RSuS2 proteins in both sucrose-starved and sucrose-provided cells may allow the cells to respond to sugar availability immediately.

\section{Introduction}

In higher plants, sucrose is a principle product of photosynthesis, a major form of translocated carbon and an important substrate for growth. Utilization of sucrose as a source of carbon and energy depends on its cleavage into hexoses. Both sucrose and hexoses can also act as direct or indirect regulators of gene expression (Koch 1996). The cleavage of sucrose in plants is catalysed either by invertase ( $\beta$-D-fructofuranoside fructohydrolase, EC 3.2.1.26) or by sucrose synthase (UDP-glucose: D-fructose 2- $\alpha$-D-glucosyl transferase, EC 2.4.1.13, SuS). The former hydrolyses sucrose into fructose and glucose and the latter converts sucrose and UDP into fructose and UDP-glucose. Both enzymes are crucial for plant development, growth and carbon partitioning (Sturm and Tang 1999).

Although the reaction catalysed by $\mathrm{SuS}$ is reversible, it is thought that the enzyme mainly acts in the cleavage direction and its activity has been linked to starch synthe- sis (Chourey and Nelson 1976, Déjardin et al. 1997), cellulose synthesis (Amor et al. 1995, Carlson and Chourey 1996, Chourey et al. 1998, Nakai et al. 1999, Salnikov et al. 2001), phloem loading/unloading (Yang and Russell 1990, Martin et al. 1993, Nolte and Koch 1993, Fu and Park 1995, Guerin and Carbonero 1997, Wang et al. 1999) and sink strength (Sun et al. 1992, Wang et al. 1993, Zrenner et al. 1995). Multiple isoforms of SuS that are encoded by two or three genes have been found in a number of plant species, such as maize (Echt and Chourey 1985, Shaw et al. 1994, Carlson et al. 2002), sugarcane (Buczynski et al. 1993), carrot (Šebková et al. 1995), barley (Guerin and Carbonero 1997), rice (Yu et al. 1992, Huang et al. 1996, Huang and Wang 1998) and pea (Barratt et al. 2001). Expression of different Sus genes is spatially and temporally regulated and is differentially modulated in response to anoxia, low temperatures and osmotic stress (Maraña et al. 1990,

Abbreviations - ActD, actinomycin D; CHX, cycloheximide; 2-dG, 2-deoxyglucose; 6-dG, 6-deoxyglucose; 3-OMG, 3-O-methyl glucose; Sh1, shrunken 1; SPS, sucrose phosphate synthase; Sus, gene for sucrose synthase; SuS, protein encoded by Sus. 
Chourey et al. 1991, Crespi et al. 1991, Zeng et al. 1998, Déjardin et al. 1999). Moreover, the expression of Sus genes is also differentially affected by sugars (Salanoubat and Belliard 1989, Koch et al. 1992, Fu and Park 1995, Fu et al. 1995, Godt et al. 1995, Huang et al. 1996, Koch 1996, Komatsu et al. 2002). For example, in maize, the shrunken $1(S h l)$ gene is maximally expressed under conditions of limited carbohydrate supply, whereas Sus1 is upregulated when sugars are abundant (Koch et al. 1992). In detached potato leaves, only transcription of Sus4 gene is inducible by sucrose, while expression of Sus3 remains unaffected under the same conditions (Fu and Park 1995).

In rice, sucrose synthase (RSuS) is encoded by three genes, RSusl, RSus2 and RSus3 (Wang et al. 1992, Huang et al. 1996). The gene products of RSusl and $R S u s 2$ are ubiquitously present in suspension-cultured cells, roots and leaves of etiolated seedlings while those of RSus3 are predominantly found in rice seeds (Wang et al. 1999). According to their tissue-specific and temporal distributions in the developing rice seeds, different roles have been suggested for these three RSuS isoforms. RSuS1 has been postulated as playing a role related to sucrose transport into endosperm cells. The reaction catalysed by RSuS3 has been suggested as providing the precursor for starch synthesis. Finally, RSuS2 may play a housekeeping role since it is ubiquitously and constitutively expressed (Wang et al. 1999). In the present study, the suspension-cultured cells of rice were investigated as to whether RSusl and RSus 2 expression is affected by sucrose transported into cells. Suspension-cultured cells of rice are heterotrophic and respond to exogenously applied sugars readily, and complicated results due to the spatial and developmental regulation can be avoided. The results indicate that RSus 1 is induced by sucrose, glucose and fructose, and its expression is regulated at the transcriptional and the post-transcriptional levels. An unexpected finding of the study is that the expression of RSus 2 requires newly synthesized proteins induced by sucrose and/or starvation. RSus 2 may have an important biological function in rice cells other than as a housekeeping gene.

\section{Materials and methods}

\section{Plant materials}

The suspension-cultured cells of rice (Oryza sativa L.cv. Tainung 67) were maintained in modified liquid N6 media containing Chu basal salts (Chu et al. 1975) and supplemented with $3 \%(\mathrm{w} / \mathrm{v})$ sucrose, $0.1 \%(\mathrm{w} / \mathrm{v})$ casamino acid, $1 \mathrm{mgl}^{-1}$ thiamine- $\mathrm{HCl}, 0.5 \mathrm{mgl}^{-1}$ nicotinic acid, $0.5 \mathrm{mgl}^{-1}$ pyridoxine- $\mathrm{HCl}$ and $2 \mathrm{mgl}^{-1}$ 2,4-dichlorophenoxyacetic acid. Cultures were incubated at $25^{\circ} \mathrm{C}$ in the dark with a rotation of 120 r.p.m.

Before sugar treatment, the 3-day-old, logarithmically growing cells were rinsed and incubated with a fresh medium devoid of sucrose but containing $1.64 \%(\mathrm{w} / \mathrm{v})$ mannitol for $48 \mathrm{~h}$ to lower the internal level of sugars. Cells were then transferred to fresh media with or with- out sugars. Sugars, sugar analogues and other chemicals were added to the medium at the reported concentrations. Cells were collected at desired time points by filtration through filter papers, quickly washed with sucrose-free media, blot-dried on paper towels and immediately frozen in liquid nitrogen. The frozen cells were stored at $-80^{\circ} \mathrm{C}$ until use.

\section{Isolation of total RNA and Northern analysis}

The frozen suspension-cultured cells were ground in liquid nitrogen to a fine powder using a pestle and mortar. Total RNA was isolated using TRIZOL reagent (Life Technologies/Gibco-BRL, Cleveland, USA) according to the protocol suggested by the manufacturer. Fifteen micrograms of total RNA from each sample were separated on $1.2 \%(\mathrm{w} / \mathrm{v})$ agarose gels containing formaldehyde (Lehrach et al. 1977) and then blotted to positively charged nylon membranes (Immobilon-Ny + , Millipore, Bedford, USA) using $10 \times \operatorname{SSPE}(1.5 \mathrm{M}$ $\mathrm{NaCl}, 100 \mathrm{~m} M$ sodium phosphate, $10 \mathrm{~m} M$ EDTA, $\mathrm{pH}$ 7.4). The transferred nucleic acids were UV crosslinked to membranes. Prehybridization and hybridization were done as described by Sambrook et al. (1989). After hybridization, the blots were washed twice for $10 \mathrm{~min}$ at room temperature with $2 \times \mathrm{SSPE}, 0.1 \% \mathrm{SDS}$, washed once for $15 \mathrm{~min}$ at $42^{\circ} \mathrm{C}$ with $1 \times \mathrm{SSPE}, 0.1 \%$ SDS, and then washed once with $0.1 \times$ SSPE, $0.1 \%$ SDS for $15 \mathrm{~min}$ at $61^{\circ} \mathrm{C}$ for the $R S u s 2$ gene-specific probe or at $68^{\circ} \mathrm{C}$ for the $R S u s 1$ and the $18 \mathrm{~S}$ rRNA gene-specific probes. The blots were exposed to X-ray films or phosphor-imaging plates and the captured images were analysed with a Bio Imaging Analyser (Fujix BAS1000, Fuji Photo Film, Tokyo, Japan).

\section{Preparation of DNA probes}

The DNA probes specific for RSus1 and RSus2 were synthesized by PCR using plasmids containing the RSus1 and RSus2 cDNAs (Yu et al. 1992, Huang et al. 1996), respectively, as templates. The sequences of the primers that were selected from the $3^{\prime}$-untranslated region of each cDNA were as follows: RSusl forward primer, $5^{\prime}$-TAGGTAACCTGGAGAGGCGTGAAAC- $3^{\prime}$ (nucleotides 2431-2455). RSus 1 reverse primer, 5'-ATGGAATTCCAGAAACGGCACCAAG- ${ }^{\prime}$ (nucleotides 2855-2831). RSus2 forward primer, 5'-TGCATCTTCAGCAGGAGAAG-3' (nucleotides 2531-2550). RSus2 reverse primer, $5^{\prime}$-CAGGAACCGGCGTTTATTTGA- $3^{\prime}$ (nucleotides 2692-2672).

The specificity of each probe was verified by cross Southern hybridization (data not shown). For preparing the probe for 18S rRNA, an 1.6-kb DNA fragment containing a part of the rice $18 \mathrm{~S}$ rRNA gene was PCR amplified from rice genomic DNA with the forward primer (5'-GAACGAATTCGAACTGTGAAACTGC- $\left.{ }^{\prime}\right)$ and the reverse primer (5'-TACAAACTGCAGGGACGTAGTCAA- $3^{\prime}$ ). The amplified DNA fragment was subjected to sequencing for confirmation. 
For use in the Northern hybridization, both the RSus1-specific probe and the 18S rRNA-specific probe were labelled with $\left[\alpha_{-}{ }^{32} \mathrm{P}\right] \mathrm{dCTP}\left(3000 \mathrm{Ci} \mathrm{mmol}^{-1}\right)(\mathrm{NEN}$, Boston, USA) using a random prime labelling system (Amersham Pharmacia Biotech, Bucks, UK). The RSus2-specific probe was labelled with $\left[\alpha_{-}{ }^{32} \mathrm{P}\right] \mathrm{dATP}$ $\left(3000 \mathrm{Ci} \mathrm{mmol}^{-1}\right)$ by PCR.

\section{Nuclear run-on transcription assays}

Nuclei isolation was performed as described by Manzara and Gruissem (1995) but using a different homogenization buffer (10 $\mathrm{m} M$ Tris- $\mathrm{HCl}, \mathrm{pH} 7.2 ; 5 \mathrm{mM} \mathrm{MgCl} 2,0.5 M$ sucrose, and $5 \mathrm{~m} M$ 2-mercaptoethanol) and a different nuclei storage buffer (20 $\mathrm{m} M$ HEPES-KOH, pH 7.2; $5 \mathrm{mM} \mathrm{MgCl} 2,50 \%$ glycerol, $5 \mathrm{mM}$ 2-mercaptoethanol).

For RNA synthesis, $75 \mu \mathrm{l}$ nuclei were mixed with $75 \mu \mathrm{l}$ of $2 \times$ assay buffer $(40 \mathrm{~m} M$ HEPES-KOH, pH 7.9; $20 \mathrm{~m} M$ $\mathrm{MgCl}_{2}, 200 \mathrm{mM}\left(\mathrm{NH}_{4}\right)_{2} \mathrm{SO}_{4}, 20 \%$ glycerol, $5 \mathrm{~m} M$ dithiothreitol, $1 \mathrm{~m} M$ each of ATP, GTP and CTP) containing 200 units RNasin (Promega, Madison, USA) and $150 \mu \mathrm{Ci}\left[\alpha_{-}{ }^{32} \mathrm{P}\right] \mathrm{UTP}\left(3000 \mathrm{Cimmol}^{-1}\right)$. The reaction was incubated at $25^{\circ} \mathrm{C}$ for $30 \mathrm{~min}$ and followed by the addition of $10 \mu \mathrm{l}$ of $1 \mathrm{mM}$ UTP and incubated at $25^{\circ} \mathrm{C}$ for another $30 \mathrm{~min}$. Five units of RQ1 RNase-free DNase (Promega) were then added and incubated at $25^{\circ} \mathrm{C}$ for $10 \mathrm{~min}$ to remove the template. The synthesized RNA was purified by phenol/chloroform/isoamyl alcohol (25:24:1 [v/v/v], $\mathrm{pH} 4.5)$ extraction and then precipitated with $100 \mu \mathrm{g}$ of yeast tRNA (Life Technologies/GibcoBRL) using isopropanol. The RNA pellet was dissolved in diethyl pyrocarbonate-treated water.

For dot blot hybridization, unlabelled RSus 1 -specific probe, $R S u s 2$-specific probe, $18 \mathrm{~S}$ rRNA-specific probe and the plasmid pBluescript were denatured and dot blotted onto positively charged nylon membranes as described by Ausubel et al. (1987). Blots were hybridized with labelled RNA and washed as described for the Northern blot analysis.

\section{Enzyme extraction, polyacrylamide gel electrophoresis and Western analysis}

The frozen suspension-cultured cells were ground to a fine powder in liquid nitrogen. An equal volume (v/w) of PB-7.0 (50 $\mathrm{m} M$ sodium phosphate, $\mathrm{pH} 7.0 ; 1 \mathrm{~m} M$ EDTA, $1 \mathrm{~m} M$ 2-mercaptoethanol) was added and mixed. The homogenates were centrifuged at $12000 \mathrm{~g}$ and $4^{\circ} \mathrm{C}$ for $30 \mathrm{~min}$. The resulting supernatants were used for polyacrylamide gel electrophoresis (PAGE) and Western analysis.

The proteins were separated by $10 \%$ SDS-PAGE according to Laemmli (1970) and transferred onto polyvinylidene difluoride (PVDF) membranes (Millipore). For the detection of the RSuS1 protein, a monoclonal antibody that recognizes RSuS1 and RSuS3, but not $\mathrm{RSuS} 2$, was used. Because the expression of RSus3 is seed-specific (Wang et al. 1999), only RSuS1 proteins can be detected by this antibody in suspension-cultured cells. In the case of RSuS2, a monospecific antipeptide antibody (Wang et al. 1999) was used for immunodetection.

\section{Results}

\section{Accumulation of RSus1 and RSus2 mRNA in sugar-depleted and sugar-fed cells}

To study the effect of exogenously provided sugars on the expression of RSus genes, cells cultured in a sucrosecontaining medium for 3 days were transferred to a fresh medium devoid of sucrose to deplete the endogenous sugars. Mannitol was added to the medium to maintain the same osmotic pressure and to avoid changes in gene expression caused by osmotic shock. Cells were then collected after different periods of time up to $48 \mathrm{~h}$, and the steady-state levels of RSus 1 and RSus 2 mRNA in cells were examined by Northern analysis using the genespecific probes. As shown in Fig. 1A, the levels of RSus 1 mRNA gradually decreased and became undetectable within $48 \mathrm{~h}$ of culture in the sucrose-free medium, while the changes in RSus 2 mRNA levels were less pronounced. When the 48-h-starved cells were transferred to fresh media containing various sugars at a concentration of $100 \mathrm{mM}$, the RSusl mRNA began to accumulate after $2-3 \mathrm{~h}$ of sucrose, glucose or fructose feeding (Fig. 1B). After 12-16h, the RSus1 transcripts reached a maximal level and then reduced. An accumulation of RSus 1 mRNA was not observed in mannitol-fed cells, indicating that the expression of RSus 1 after cells being transferred to sugar-containing medium was sugardependent, and was not a response to changes in osmotic pressure. The accumulation of transcripts caused by sugars was also observed for the RSus 2 gene. However, in contrast to RSus1, the steady-state levels of the RSus 2 mRNA in the starved cells increased on transfer to mannitol-containing media. This was not due to the changes in osmotic pressure because the transcript levels of RSus 2 in cells cultured with different concentrations of mannitol were similar (data not shown).

\section{Effect of sucrose on the mRNA stability and transcriptional activity of $R$ Sus genes}

To unravel the mechanism that regulates the expression of the RSus genes, both the mRNA stability and the transcriptional activity of RSus 1 and RSus 2 in sucrosefed and sucrose-depleted cells were examined. The 48h-starved cells were cultured with sucrose for $24 \mathrm{~h}$, and then treated with $10 \mu \mathrm{g} \mathrm{ml}^{-1}$ actinomycin D (ActD), an inhibitor of transcription, in the presence of sucrose for $12 \mathrm{~h}$. This should result in more than $95 \%$ inhibition of transcription (Sheu et al. 1994). The patterns of changes in mRNA level were similar for both RSus 1 and RSus2 during the subsequent $12-\mathrm{h}$ period of incubation with ActD, regardless of the presence (Fig. 2A) or absence (Fig. 2B) of sucrose in the medium. To estimate the mRNA half-lives of the two genes, the hybridization 
A

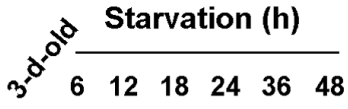

RSus1

RSus2

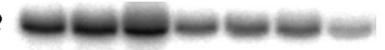

$18 S$ rRNA

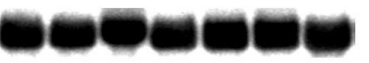

B
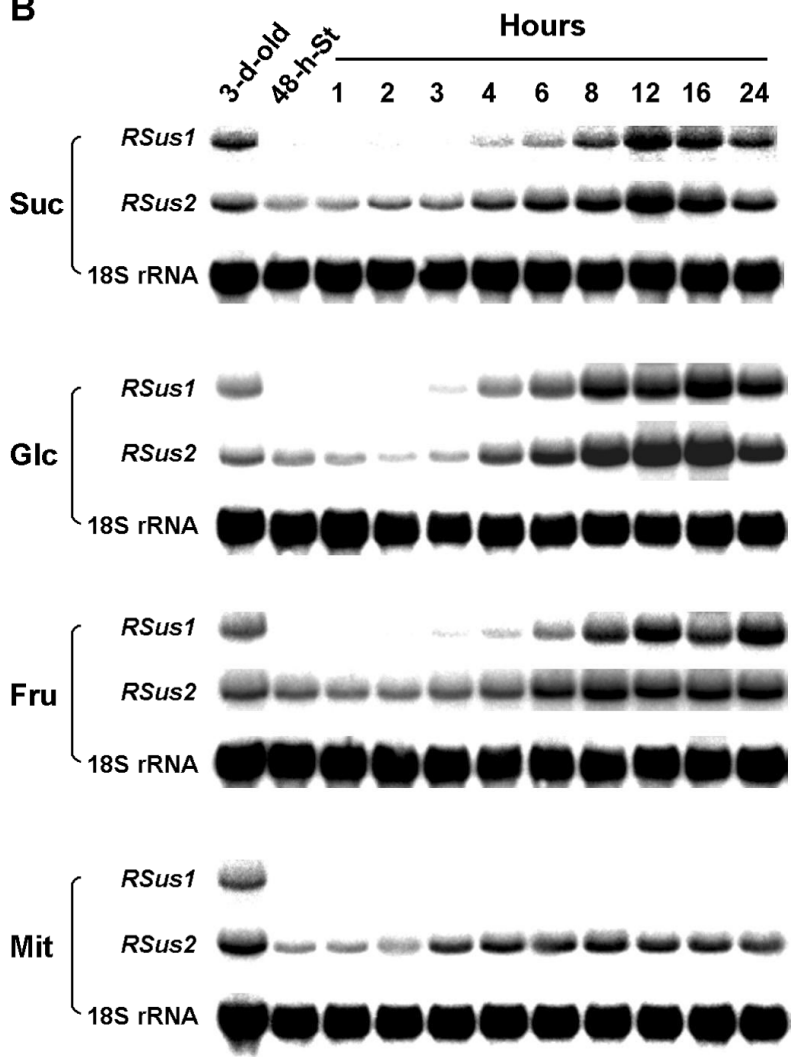

Fig. 1. Time course analysis of changes in the steady-state levels of the RSus mRNA in sugar-depleted and sugar-fed suspensioncultured cells. Cells cultured in a sucrose-containing medium for 3 days (3-d-old) were transferred to a sucrose-free medium (containing $1.64 \%$ mannitol) for $48 \mathrm{~h}$ (A). After 48 -h starvation (48-h-St), the cells were incubated in fresh media containing $100 \mathrm{~m} M$ sucrose (Suc), glucose (Glc), fructose (Fru) or mannitol (Mit) for $24 \mathrm{~h}$ (B). Cells were collected at indicated time. Total RNA from the cells was isolated and an equal amount of RNA $(15 \mu \mathrm{g})$ was loaded into each lane of formaldehyde agarose gels and analysed by Northern blot hybridization. Identical blots were hybridized with RSus1-specific, RSus2-specific and 18S rRNAspecific probes.

signals in Fig. 2 were quantified densitometrically, and the values were normalized relative to the amount of $18 \mathrm{~S}$ rRNA (data not shown). The estimated half-life of RSus 1 mRNA in sucrose-fed cells and in sucrosedepleted cells was $13.8 \mathrm{~h}$ and $14.7 \mathrm{~h}$, respectively. The mRNA half-life of RSus 2 was approximately 1.5 -fold longer in sucrose-depleted cells than in sucrose-fed cells, which are $16.6 \mathrm{~h}$ and $11.4 \mathrm{~h}$, respectively. The results revealed that changing sucrose levels did not alter the
A

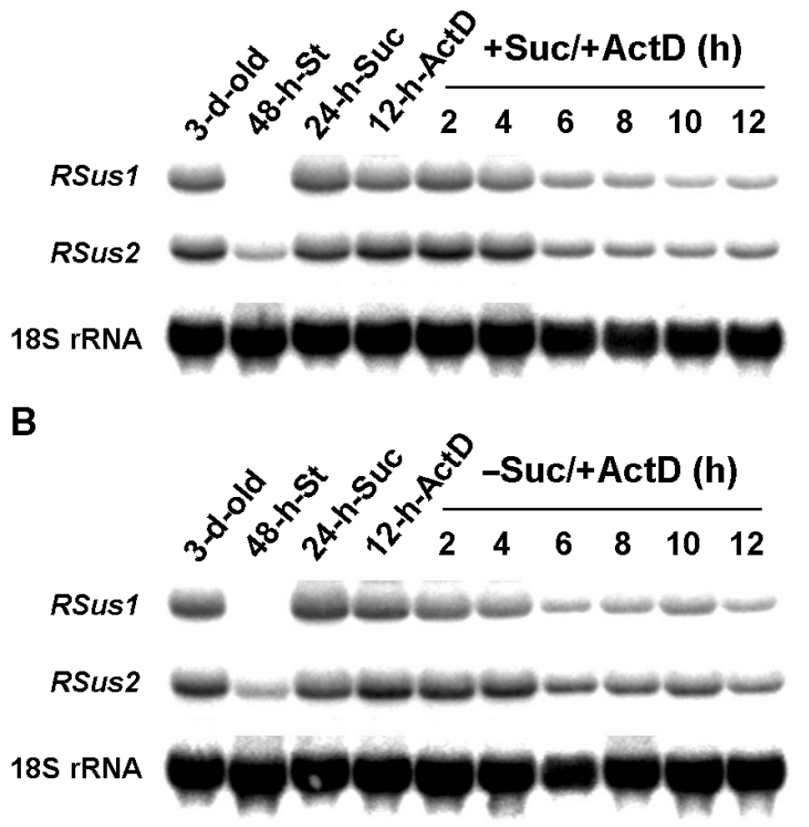

Fig. 2. Effect of sucrose on the stability of RSus mRNA. Cells cultured in a sucrose-containing medium for 3 days (3-d-old) were starved for $48 \mathrm{~h}$ (48-h-St) and then cultured in a medium containing sucrose for $24 \mathrm{~h}$ (24-h-Suc) to achieve a high starting level of mRNA. After transferring to medium containing sucrose $(100 \mathrm{mM})$ and ActD $\left(10 \mu \mathrm{g} \mathrm{ml}^{-1}\right)$ for another $12 \mathrm{~h}(12-\mathrm{h}-\mathrm{ActD})$, the cells were subsequently incubated in fresh media containing both sucrose and ActD (A) or lacking sucrose but with ActD (B) for $12 \mathrm{~h}$. Samples were collected every $2 \mathrm{~h}$. Total RNA from the cells was isolated and an equal amount of RNA $(15 \mu \mathrm{g})$ was loaded into each lane of formaldehyde agarose gels and analysed by Northern blot hybridization. Identical blots were hybridized with RSusl-specific, RSus2-specific and $18 \mathrm{~S}$ rRNA-specific probes.

stability of RSus 1 mRNA, but RSus 2 mRNA was more stable under sucrose-deprivation conditions.

Figure 3 shows the results of nuclear run-on transcription of RSus genes with nuclei isolated from sucrose-fed and sucrose-depleted cells. The transcriptional activity of RSus 1 in cells starved for sucrose was undetectable but was high in cells fed with sucrose, showing that transcriptional regulation was involved in the sucrose-modulated expression of RSus1. The transcription rates of RSus2 were similar in cells grown in the sucrose-free and sucrose-containing media, suggesting that there was constitutive expression of RSus 2 mRNA in cells under varying sugar availability.

\section{Requirement of de novo protein synthesis for RSus expression}

To assess whether newly synthesized proteins are essential for the sugar-modulated expression of RSus genes, the 48-h-starved cells were cultured in sucrose-free or sucrose-supplemented media with or without cycloheximide (CHX) added. The addition of CHX completely abolished the induction of RSus 1 expression by sucrose 


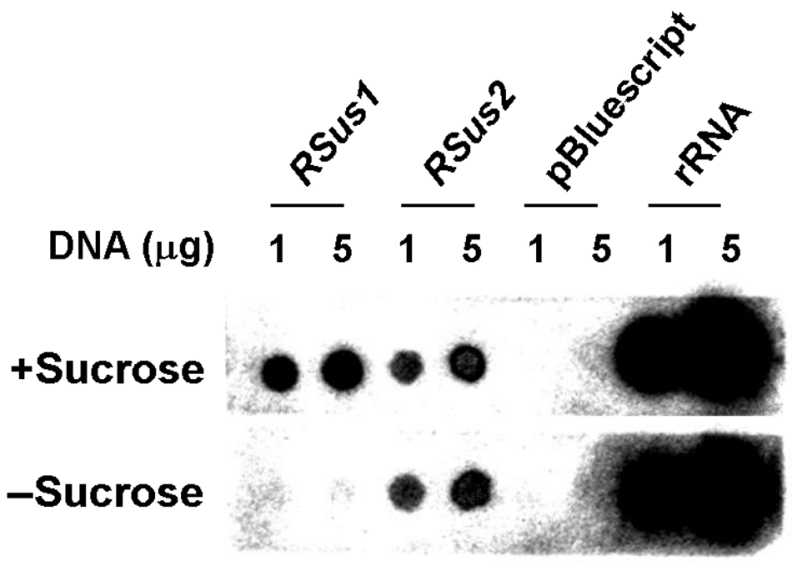

Fig. 3. Transcriptional activity of $R S u s$ genes in sucrose-fed and sucrose-depleted cells. Nuclei were isolated from cells that had been starved for $48 \mathrm{~h}$ and then transferred to fresh media with or without sucrose for $24 \mathrm{~h}$. Run-on transcription reactions were carried out as described in Materials and methods. DNA fragments of unlabelled $R S u s 1$-specific probe, RSus2-specific probe, $18 \mathrm{~S}$ rRNA-specific probe and the plasmid pBluescript DNA (as a negative control) were denatured and dot blotted onto positively charged nylon membranes in different quantities. ${ }^{32} \mathrm{P}$-labelled RNA from run-on transcription was hybridized to the DNA immobilized on membranes.

(Fig. 4A). The accumulation of RSus 1 mRNA was restored when the 12.5-h CHX-treated cells were transferred to a CHX-free but sucrose-containing medium (Fig. 4A, the last lane). It indicated that de novo protein synthesis was needed for the induction of RSusl by sucrose. Unexpectedly, the accumulation of RSus2 mRNA observed in sucrose-fed (Fig. 4B) and sucrosedepleted cells (Fig. 4D) was inhibited by CHX (Fig. 4A,C). The transcript levels of RSus2 were reduced significantly and were undetectable by the 12-h time point in the CHX-treated cells, regardless of the presence or absence of sucrose (Fig. 4A,C). When the 12.5-h $\mathrm{CHX}$-treated cells were transferred to a CHX-free medium, the accumulation of RSus2 mRNA was observed again (Fig. 4A,C, the last lane). These results showed that addition of CHX not only suppressed any further increase in RSus 2 mRNA levels but also led to a decrease in half-life of RSus 2 mRNA in both sucrosefed (Fig. 4A,B) and sucrose-depleted cells (Fig. 4C,D). CHX negatively affected the transcription and/or the stability of RSus 2 mRNA.

\section{The protein levels of RSuS in sugar-depleted and sugar-fed} cells

To determine whether the protein levels of RSuS were also affected by sugar availability, SDS-Western analyses were performed using a monoclonal antibody specifically recognizing RSuS1 in suspension-cultured cells (Materials and methods) and an RSuS2 monospecific antibody (Wang et al. 1999). Although the accumulation of RSus 1 mRNA was hardly detected after 48-h starvation (Fig. 1A), RSuS1 protein was still present in 48-h-starved
A

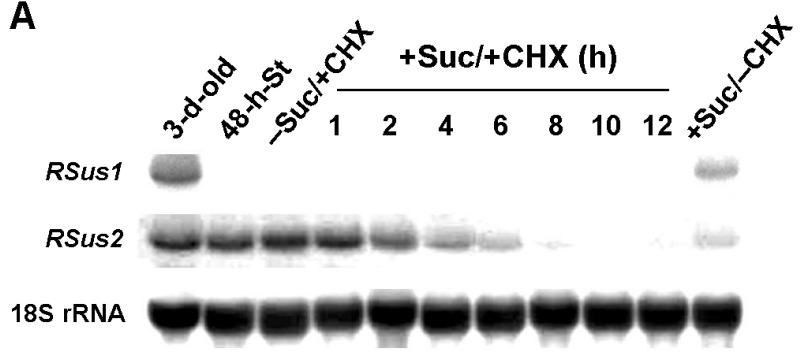

B

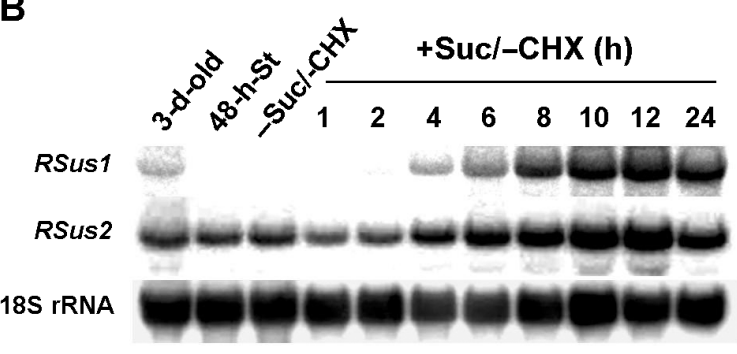

C

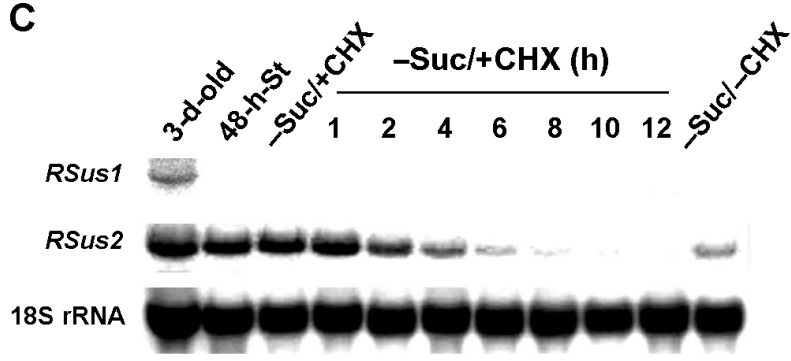

D

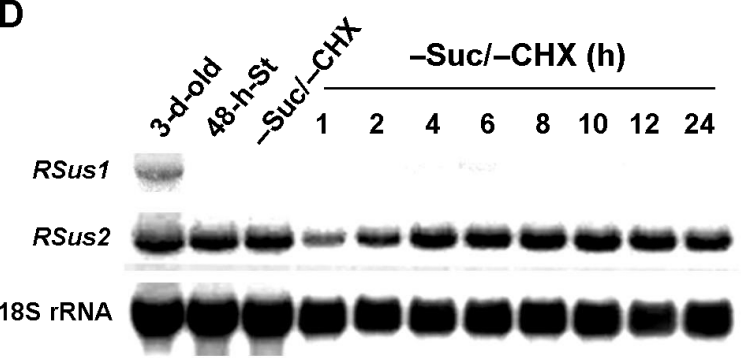

Fig. 4. Effect of cycloheximide on RSus expression in a sucrose-free or a sucrose-containing medium. 3-d-old cells were starved for $48 \mathrm{~h}$ (48-h-St) and then divided into two halves. Half the cells were preincubated with $200 \mu M$ CHX in sucrose-free medium for $30 \mathrm{~min}$ (A and $\mathrm{C},-\mathrm{Suc} /+\mathrm{CHX}$ ). Then cells were subsequently transferred to media with (A) or without (C) sucrose but containing $200 \mu M$ $\mathrm{CHX}$ for up to $12 \mathrm{~h}$ and returned to media without $\mathrm{CHX}(+\mathrm{Suc} /-$ CHX in A or $-\mathrm{Suc} /-\mathrm{CHX}$ in C). The other half was transferred to fresh medium devoid of sucrose and CHX for $30 \mathrm{~min}$ (B and $\mathrm{D},-$ Suc/ - CHX) and then incubated in media with (B) or without sucrose (D). Cells were collected at indicated time. Total RNA of the cells was isolated and an equal amount of RNA $(15 \mu \mathrm{g})$ was loaded in each lane and analysed by Northern blot hybridization. Identical blots were probed with RSus1, RSus2 and 18S rRNA probes.

cells (Fig. 5), showing that the turnover rate of RSuS1 proteins was much slower than that of RSus 1 mRNA. We therefore examined the changes in protein abundance over a longer period. As shown in Fig. 5, the RSuS1 protein level was a little higher in sucrose-fed cells than 


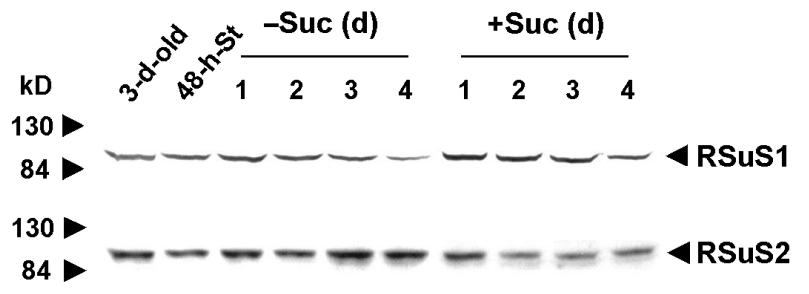

Fig. 5. Effect of sugar availability on the protein levels of RSuS. Cells cultured in a sucrose-containing medium for 3 days (3-d-old) were starved for $48 \mathrm{~h}(48-\mathrm{h}-\mathrm{St})$ and then transferred to fresh media containing $100 \mathrm{~m} M$ mannitol (-Suc) or sucrose (+ Suc). Cells were collected at the indicated times. An equal volume of crude protein extract from the cells was loaded into each lane of SDSpolyacrylamide gels, and Western analyses of RSuS1 and RSuS2 proteins were carried out using a monoclonal antibody specifically recognizing RSuS1 in suspension-cultured cells and an RSuS2 monospecific antibody. Molecular weight markers are shown at the left margin.

in sucrose-starved cells and a gradual reduction was observed in both types of cells over 4 days of culture. The level of RSuS2 protein elevated in cells under prolonged sucrose starvation conditions and a reciprocal change was observed in the sucrose-fed cells.

\section{Effects of glucose analogues and glucosamine on $\mathbf{R S u s}$ expression}

Recent studies indicate that sugar signalling in plants can occur through a number of paths including the hexokinasedependent pathway, the hexose-dependent but hexokinaseindependent pathway, and the sucrose-specific sensing and signalling pathways (Gibson 2000, Koch et al. 2000, Smeekens 2000). A number of sugar analogues have been used to characterize plant sugar responses and response pathways in a number of studies. These include glucose analogues such as L-glucose, which is not recognized by hexose transporters and is attributable to an osmotic effect, 3-O-methyl glucose (3-OMG) and 6-deoxyglucose (6-dG), which are taken up by cells but are poor substrates for hexokinase, and 2-deoxyglucose (2-dG) and mannose (Man), which can be phosphorylated by hexokinase but are poorly metabolized thereafter (Graham et al. 1994, Jang and Sheen 1994, Roitsch et al. 1995, Umemura et al. 1998). Figure 6 shows the effects of these non-metabolizable sugar analogues at non-toxic concentrations (Umemura et al. 1998) on the expression of the RSus genes. None of these glucose analogues triggered RSus 1 expression, showing that the expression of RSusl is independent of osmotic effects and hexose transporters and hexokinases are not involved in the sugar-sensing pathway controlling RSus1 expression. 3-OMG and mannose at lower concentrations cannot activate $R S u s 1$ gene expression as well, confirming that the effect of the two sugar analogues at $50 \mathrm{~m} M$ is not due to their toxicity on cells (data not shown). Glucosamine, a hexokinase inhibitor, was used for further confirmation. As shown in Fig. 7, addition of glucosamine to the media did not hamper the induction of RSusl expression by sucrose, glucose and fructose, but led to a

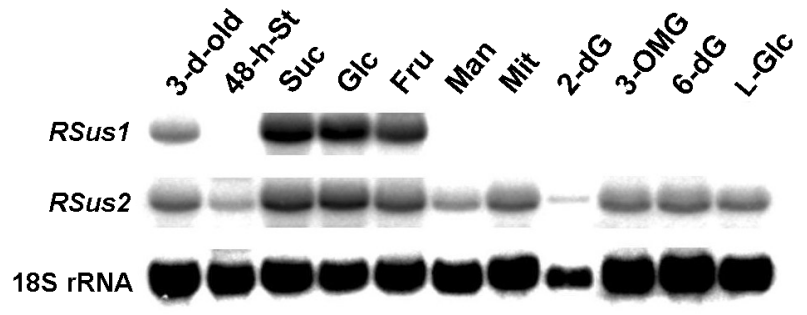

Fig. 6. Effect of sugar analogues on the expression of RSus genes. Cells cultured in a sucrose-containing medium for 3 days (3-d-old) were starved for $48 \mathrm{~h}$ (48-h-St) and then transferred to fresh media containing $50 \mathrm{~m} M$ sucrose (Suc), $50 \mathrm{~m} M$ glucose (Glc), $50 \mathrm{mM}$ fructose (Fru), $50 \mathrm{~m} M$ mannose (Man), $50 \mathrm{~m} M$ mannitol (Mit), $0.9 \mathrm{mM}$ 2-deoxyglucose (2-dG), $50 \mathrm{mM}$ 3-O-methyl glucose (3-OMG), $9 \mathrm{mM}$ 6-deoxyglucose (6-dG), or $50 \mathrm{mM}$ L-glucose (L-Glc) for $24 \mathrm{~h}$. Total RNA from the cells was isolated and an equal amount of RNA $(15 \mu \mathrm{g})$ was loaded into each lane of formaldehyde agarose gels and analysed by Northern blot hybridization. Identical blots were hybridized with RSus 1 -specific, RSus2-specific and 18S rRNA-specific probes. The addition of 2-dG, which was shown by Umemura et al. (1998) not to have any toxic effects at $0.9 \mathrm{~m} M$ on rice embryos, resulted in an inhibition of cell growth and a degradation of rRNA.

small reduction in both RSus 1 and RSus 2 mRNA levels. Similar effects were observed when glucosamine was at a concentration lower than $50 \mathrm{mM}$ (data not shown). The accumulation of RSus 2 mRNA was observed when cells were fed with the above non-metabolizable glucose analogues (Fig. 6), but it was not possible to reach a conclusion on whether the induction was triggered by these glucose analogues or by sugar starvation.

\section{Discussion}

\section{Sugar-modulated expression of RSus 1 and $R S u s 2$ are differentially regulated}

In maize, the genes encoding for SuS, Susl and Sh1, show contrasting carbohydrate responses; that is, $S u s l$ is upregulated while $S h l$ is downregulated in the presence

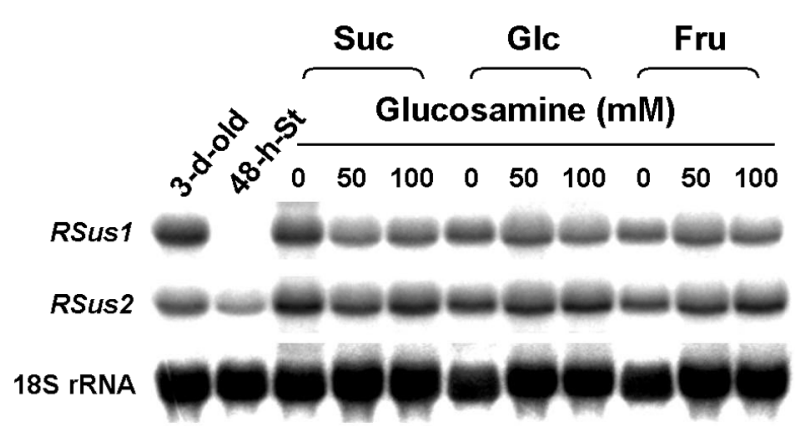

Fig. 7. Effect of glucosamine on RSus expression in the presence of sugars. Cells cultured in a sucrose-containing medium for 3 days (3-d-old) were starved for $48 \mathrm{~h}(48-\mathrm{h}-\mathrm{St})$ and then transferred to media containing $50 \mathrm{mM}$ sucrose (Suc), glucose (Glc) or fructose $(\mathrm{Fru})$ in the presence or absence of glucosamine for $24 \mathrm{~h}$. Total RNA from the cells was isolated and an equal amount of RNA $(15 \mu \mathrm{g})$ was loaded into each lane of formaldehyde agarose gels and analysed by Northern blot hybridization. Identical blots were hybridized with RSus 1 -specific, RSus2-specific and $18 \mathrm{~S}$ rRNA-specific probes. 
of abundant carbohydrate supplies (Koch 1996). In the suspension-cultured cells used in this study, we demonstrated that the Susl-type gene in rice, RSusl, is also upregulated by sugars. However, RSus2, the Sh1type gene, is sugar as well as starvation upregulated (Fig. 1B, and Fig. 4C,D). Possession by the same gene of a similar response to the two contrasting carbohydrate levels is unusual, and, to our knowledge, this is the first case among Sus genes.

Sucrose-modulated expression of RSus 1 was regulated at the transcriptional level as revealed from that the transcription activity of $R S u s 1$ significantly increased in the presence of sucrose (Fig. 3), but the stability of the transcribed RSus 1 mRNA was not affected by sucrose abundance (Fig. 2). However, the small difference between the protein level of RSuS1 in sucrose-fed cells and that in sucrose-depleted cells (Fig. 5) indicated that there are other mechanisms involved in regulating $R S u s 1$ expression. In the sucrose-starved cells, the RSus 1 mRNA could hardly be detected after $48 \mathrm{~h}$ of sucrose starvation (Fig. 1A,B) but the RSuS1 proteins were still present in cells even after prolonged sucrose starvation (Fig. 5). A possible explanation is that the RSuS1 proteins are extremely stable in sucrose-starved cells. In a previous study, we reported that the gene products of RSus 1 and RSus2 formed homo- and hetero-tetrameric $\mathrm{RSuS}$ isoforms in etiolated rice seedlings (Huang and Wang 1998). RSuS1 might be stabilized through the formation of heterotetramers with RSuS2 since the $R S u s 2$ gene was expressed under sucrose starvation conditions, and the RSuS2 protein level was even higher in sucrose-starved cells than in sucrose-fed cells. Regulation of RSus2 was different from that of RSus1. First, the stability of RSus 2 mRNA was higher in sucrose-starved cells, suggesting that post-transcriptional regulation of $R S u s 2$ occurred. Second, although the transcriptional activity of RSus 2 in sucrose-fed and sucrose-starved cells was similar, the transcription and/or the stability of RSus 2 mRNA, was negatively affected by CHX. The results showed that newly synthesized proteins induced by sucrose or by sucrose starvation were involved in the regulation of $R S u s 2$ expression at transcriptional and/or post-transcriptional levels. Furthermore, the changes in mRNA level and those in protein level did not show marked differences, except that the level of RSuS2 protein was higher under prolonged sucrose starvation conditions. However, it may attribute to the higher stability of the RSus 2 mRNA in sucrose-starved cells.

\section{Hexose uptake per se and the phosphorylation of hexoses by hexokinase are not involved in the sugar-sensing pathway controlling RSus 1 expression}

In suspension-cultured cells of Chenopodium rubrum, the addition of either glucose or 6-dG induced the expression of the Sus gene, suggesting that the non-phosphorylated glucose is the signal for sugar-induced gene expression (Godt et al. 1995). In this study, it was found that hexose uptake per se and the phosphorylation of hexoses by hexokinase were not involved in the sugar-sensing pathway controlling RSusl expression since 3-OMG, 6-dG and mannose did not induce RSus1 (Fig. 6). However, addition of glucosamine resulted in a reduction in the RSus1 mRNA level (Fig. 7), suggesting that the catalytic function of hexokinase in cells was required to maintain the maximal expression of RSus1.

It is unclear how hexoses and sucrose modulate the induction of RSus and whether the expressions of RSus 1 and $R S u s 2$ are mediated by the same signal transduction pathway. It was found that cell wall invertase activity was high in sucrose-fed suspension-cultured cells of rice but low in glucose- or fructose-fed cells (Y.-H. Lee 1997. Thesis, National Taiwan University, Taipei, Taiwan). Therefore, in addition to being taken up via sucrose transporters, sucrose may be hydrolysed by cell wall invertases and the resulting hexoses are transported into cells by hexose transporters. The sucrose that is hydrolysed by cell wall invertases and the hexoses that are directly fed to cells may affect the expression of RSusl gene via the same pathway. It has been shown that sucrose synthesis occurs rapidly in vivo when hexoses are the sole carbon source in the unloading medium (Geigenberger and Stitt 1993, Viola 1996). Rapid turnover of sucrose, the futile cycle, has also been observed in a number of plant species (Wendler et al. 1990, Geigenberger and Stitt 1991, Nguyen-Quoc and Foyer 2001). For example, in tomato fruits, the unloaded sucrose is broken down and rapidly re-synthesized within 2 h (N'tchobo et al. 1999). Sucrose synthesis in plants is preferentially catalysed by sucrose phosphate synthase (SPS; EC 2.4.1.14), but it has been suggested that $\mathrm{SuS}$ is also able to catalyse the synthesis of sucrose (Gross and Pharr 1982, Tupy and Primot 1982, Geigenberger and Stitt 1993, Viola 1996). Recent studies indicate that $\mathrm{SuS}$ may be associated with the plasma membrane and the actin cytoskeleton in addition to being a soluble enzyme in the cytosol (Amor et al. 1995, Winter et al. 1997, 1998). We postulate that the re-synthesized sucrose either from the transported hexoses or from the unloaded sucrose may be the signal molecule for the induction of RSus expression. In this aspect, the membrane-associated $\mathrm{SuS}$ is a better candidate, being the signal producer, than the soluble SuS and SPS because the reaction catalysed by it can be distinguished from the main stream of sucrose metabolism and synthesis that occurs in the cytosol. Furthermore, the constant presence of $\mathrm{RSuS1}$ and $\mathrm{RSuS} 2$ proteins in sucrose-starved cells and sucrose-fed cells can allow the cells to respond to sugar availability immediately. Further investigation is needed to elucidate whether our hypothesis is valid and whether other signals such as the influx of sucrose into cells, sugar metabolites, etc., are required for the sugar-modulated expression of the RSus genes.

Acknowledgements - We thank Professor Li-Fei Liu, the National Taiwan University, for providing the rice suspension-cultured cells, and Zheng-Chia Tsai and Chun-Ju Chang for help in the preparation of antibodies and suspension-cultured cells. This work was supported by grants from the National Science Council, the Republic of China. 


\section{References}

Amor Y, Haigler CH, Johnson S, Wainscott M, Delmer DP (1995) A membrane-associated form of sucrose synthase and its potential role in synthesis of cellulose and callose in plants. Proc Natl Acad Sci USA 92: 9353-9357

Ausubel FM, Brent R, Kingston RE, Moore DD, Seidman JG, Smith JA, Struhl K (1987) Current Protocols in Molecular Biology. John Wiley \& Sons, New York, NY

Barratt DHP, Barber L, Kruger NJ, Smith AM, Wang TL, Martin C (2001) Multiple, distinct isoforms of sucrose synthase in pea. Plant Physiol 127: 655-664

Buczynski SR, Thom M, Chourey PS, Maretzki A (1993) Tissue distribution and characterization of sucrose synthase isozymes in sugarcane. Plant Physiol 142: 641-646

Carlson SJ, Chourey PS (1996) Evidence for plasma membraneassociated forms of sucrose synthase in maize. Mol Gen Genet 252: $303-310$

Carlson SJ, Chourey PS, Helentjaris T, Datta R (2002) Gene expression studies on developing kernels of maize sucrose synthase (SuSy) mutants show evidence for a third SuSy gene. Plant Mol Biol 49: 15-29

Chourey PS, Nelson OE (1976) The enzymatic deficiency conditioned by the shrunken-1 mutations in maize. Biochem Genet 14: 1041-1055

Chourey PS, Taliercio EW, Carlson SJ, Ruan YL (1998) Genetic evidence that the two isozymes of sucrose synthase present in developing maize endosperm are critical, one for cell wall integrity and the other for starch biosynthesis. Mol Gen Genet 259: 88-96

Chourey PS, Taliercio EW, Kane EJ (1991) Tissue-specific expression and anaerobically induced posttranscriptional modulation of sucrose synthase genes in Sorghum bicolor M. Plant Physio 96: $485-490$

Chu CC, Wang CC, Sun CS, Hsu C, Yin KC, Chu CY (1975) Establishment of an efficient medium for anther culture of rice through comparative experiments on the nitrogen sources. Sci Sin 16: 659-688

Crespi MD, Zabaleta EJ, Pontis HG, Salerno GL (1991) Sucrose synthase expression during cold acclimation in wheat. Plant Physiol 96: 887-891

Déjardin A, Rochat C, Wuillème S, Boutin JP (1997) Contribution of sucrose synthase, ADP-glucose pyrophosphorylase and starch synthase to starch synthesis in developing pea seeds. Plant Cell Environ 20: 1421-1430

Déjardin A, Sokolov LN, Kleczkowski LA (1999) Sugar/osmoticum levels modulate differential abscisic acid-independent expression of two stress-responsive sucrose synthase genes in Arabidopsis. Biochem J 344: 503-509

Echt CS, Chourey PS (1985) A comparison of two sucrose synthetase isozymes from normal and shrunken maize. Plant Physiol 79: $530-536$

Fu H, Kim SY, Park WD (1995) High-level tuber expression and sucrose inducibility of a potato Sus4 sucrose synthase gene require $5^{\prime}$ - and $3^{\prime}$-flanking sequences and the leader intron. Plant Cell 7: 1387-1394

Fu H, Park WD (1995) Sink- and vascular-associated sucrose synthase functions are encoded by different gene classes in potato. Plant Cell 7: 1369-1385

Geigenberger P, Stitt M (1991) A 'futile' cycle of sucrose synthesis and degradation is involved in regulating partitioning between sucrose, starch and respiration in cotyledons of germinating Ricinus communis L. seedlings when phloem transport is inhibited. Planta 185: 81-90

Geigenberger P, Stitt M (1993) Sucrose synthase catalyses a readily reversible reaction in vivo in developing potato tubers and other plant tissues. Planta 189: 329-339

Gibson SI (2000) Plant sugar-response pathways. Part of a complex regulatory web. Plant Physiol 124: 1532-1539

Godt DE, Riegel A, Roitsch T (1995) Regulation of sucrose synthase expression in Chenopodium rubrum: characterization of sugar induced expression in photoautotrophic suspension cultures and sink tissue specific expression in plants. Plant Physiol 146: 231-238

Graham IA, Denby KJ, Leaver CJ (1994) Carbon catabolite repression regulates glyoxylate cycle gene expression in cucumber. Plant Cell 6: 761-772
Gross KC, Pharr DM (1982) Cucumber fruit sucrose synthase isozymes. Phytochemistry 21: 1241-1244

Guerin J, Carbonero P (1997) The spatial distribution of sucrose synthase isozymes in barley. Plant Physiol 114: 55-62

Huang JW, Chen JT, Yu WP, Shyur LF, Wang AY, Sung HY, Lee PD, Su JC (1996) Complete structures of three rice sucrose synthase isogenes and differential regulation of their expressions. Biosci Biotech Biochem 60: 233-239

Huang DY, Wang AY (1998) Purification and characterization of sucrose synthase isozymes from etiolated rice seedlings. Biochem Mol Biol Int 46: 107-113

Jang JC, Sheen J (1994) Sugar sensing in higher plants. Plant Cell 6: $1665-1679$

Koch KE (1996) Carbohydrate-modulated gene expression in plants. Annu Rev Plant Physiol Plant Mol Biol 47: 509-540

Koch KE, Nolte KD, Duke ER, McCarty DR, Avigne WT (1992) Sugar levels modulate differential expression of maize sucrose synthase genes. Plant Cell 4: 59-69

Koch KE, Ying Z, Wu Y, Avigne WT (2000) Multiple paths of sugar-sensing and a sugar/oxygen overlap for genes of sucrose and ethanol metabolism. J Exp Bot 51: 417-427

Komatsu A, Moriguchi T, Koyama K, Omura M, Akihama T (2002) Analysis of sucrose synthase genes in citrus suggests different roles and phylogenetic relationships. J Exp Bot 53: 61-71

Laemmli UK (1970) Cleavage of structural proteins during the assembly of the head of bacteriophage T4. Nature 227: 680-685

Lehrach H, Diamond D, Wozney JM, Boedtker H (1977) RNA molecular weight determinations by gel electrophoresis under denaturing conditions, a critical reexamination. Biochemistry 16: 4743-4751

Manzara T, Gruissem W (1995) Identification of promoter sequences that interact with DNA-binding proteins. In: Maliga $\mathrm{P}$, Klessing DF, Cashmore AR, Gruissem W, Varner JE (eds) Methods in Plant Molecular Biology: a Laboratory Course Manual. Cold Spring Harbor Laboratory Press, New York, NY, pp 240-241

Maraña C, García-Olmedo F, Carbonero P (1990) Differential expression of two types of sucrose synthase-encoding genes in wheat in response to anaerobiosis, cold shock and light. Gene 88: $167-172$

Martin T, Frommer WB, Salanoubat M, Willmitzer L (1993) Expression of an Arabidopsis sucrose synthase gene indicates a role in metabolization of sucrose both during phloem loading and in sink organs. Plant J 4: $367-377$

N'tchobo H, Dali H, Nguyen-Quoc B, Foyer CH, Yelle S (1999) Starch synthesis in tomato remains constant throughout fruit development and is dependent on sucrose supply and sucrose synthase activity. J Exp Bot 50: 1457-1463

Nakai $\mathrm{T}$, Tonouchi $\mathrm{N}$, Konishi $\mathrm{T}$, Kojima $\mathrm{Y}$, Tsuchida $\mathrm{T}$, Yoshinaga F, Sakai F, Hayashi T (1999) Enhancement of cellulose production by expression of sucrose synthase in Acetobacter xylinum. Proc Natl Acad Sci USA 96: 14-18

Nguyen-Quoc B, Foyer CH (2001) A role for 'futile cycles' involving invertase and sucrose synthase in sucrose metabolism of tomato fruit. J Exp Bot 52: 881-889

Nolte KD, Koch KE (1993) Companion-cell specific localization of sucrose synthase in zones of phloem loading and unloading. Plant Physiol 101: 899-905

Roitsch T, Bittner M, Godt DE (1995) Induction of apoplastic invertase of Chenopodium rubrum by D-glucose and a glucose analog and tissuse-specific expression suggest a role in sinksource regulation. Plant Physiol 108: 285-294

Salanoubat M, Belliard G (1989) The steady-state level of potato sucrose synthase mRNA is dependent on wounding, anaerobiosis and sucrose concentration. Gene 84: 181-185

Salnikov VV, Grimson MJ, Delmer DP, Haigler CH (2001) Sucrose synthase localizes to cellulose synthesis sites in tracheary elements. Phytochemistry 57: 823-833

Sambrook J, Fritsch EF, Maniatis T (1989) Molecular Cloning: a Laboratory Manual, 2nd edn. Cold Spring Harbor Laboratory Press, New York, NY

Šebková V, Unger C, Hardegger M, Sturm A (1995) Biochemical, physiological, and molecular characterization of sucrose synthase from Daucus carota. Plant Physiol 108: 75-83

Shaw JR, Ferl RJ, Baier J, St. Clair D, Carson C, McCarty DR, Hannah LC (1994) Structural features of the maize sus1 gene and protein. Plant Physiol 106: 1659-1665 
Sheu JJ, Jan SP, Lee HT, Yu SM (1994) Control of transcription and mRNA turnover as mechanisms of metabolic repression of $\alpha$-amylase gene expression. Plant J 5: 655-664

Smeekens S (2000) Sugar-induced signal transduction in plants. Annu Rev Plant Physiol Plant Mol Biol 51: 49-81

Sturm A, Tang GQ (1999) The sucrose-cleaving enzymes of plants are crucial for development, growth and carbon partitioning. Trends Plant Sci 4: 401-407

Sun J, Loboda T, Sung SS, Black CC (1992) Sucrose synthase in wild tomato, Lycopersicon chmielewskii, and tomato fruit sink strength. Plant Physiol 98: 1163-1169

Tupy J, Primot L (1982) Sucrose synthetase in the latex of Hevea brasiliensis Muell. J Exp Bot 33: 988-995

Umemura T, Perata P, Futsuhara Y, Yamaguchi J (1998) Sugar sensing and $\alpha$-amylase gene repression in rice embryos. Planta 204: $420-428$

Viola R (1996) Hexose metabolism in discs excised from developing potato (Solanum tuberosum L.) tubers. Planta 198: 186-196

Wang AY, Yu WP, Juang RH, Huang JW, Sung HY, Su JC (1992) Presence of three rice sucrose synthase genes as revealed by cloning and sequencing of cDNA. Plant Mol Bio 18: 1191-1194

Yu WP, Wang AY, Juang RH, Sung HY, Su JC (1992) Isolation and sequences of rice sucrose synthase cDNA and genomic DNA. Plant Mol Bio 18: 139-142

Wang AY, Kao MH, Yang WH, Sayion Y, Liu LF, Lee PD, Su JC (1999) Differentially and developmentally regulated expression of three rice sucrose synthase genes. Plant Cell Physiol 40: 800-807

Wang F, Smith AG, Brenner ML (1993) Isolation and sequencing of tomato fruit sucrose synthase cDNA. Plant Physiol 103: 1463-1464

Wendler R, Veith R, Dancer J, Stitt M, Komor E (1990) Sucrose storage in cell suspension cultures of Saccharum sp. (sugarcane) is regulated by a cycle of synthesis and degradation Planta 183: 31-39

Winter H, Huber JL, Huber SC (1997) Membrane association of sucrose synthase: changes during the graviresponse and possible control by protein phosphorylation. FEBS Lett 420 : $151-155$

Winter H, Huber JL, Huber SC (1998) Identification of sucrose synthase as an actin-binding protein. FEBS Lett 430: 205-208

Yang NS, Russell D (1990) Maize sucrose synthase-1 promoter directs phloem cell-specific expression of Gus gene in transgenic tobacco plants. Proc Natl Acad Sci USA 87: 4144-4148

Zeng Y, Wu Y, Avigne WT, Koch KE (1998) Differential regulation of sugar-sensitive sucrose synthases by hypoxia and anoxia indicate complementary transcriptional and posttranscriptional responses. Plant Physiol 116: 1573-1583

Zrenner R, Salanoubat M, Willmitzer L, Sonnewald U (1995) Evidence of the crucial role of sucrose synthase for sink strength using transgenic potato plants (Solanum tuberosum L.). Plant J 7: 97-107 